\title{
Searching for a safe, cheap and simple protocol to desensitize children with peanut allergy, patient data of four children with peanut allergy undergoing oral immunotherapy (OIT)
}

\begin{abstract}
Objectives: To find a safe, effective and easy-to-perform method to desensitize children with peanut allergy.

Design: Patients with anaphylactic reactions to peanut protein (Sampson Grade 1-3) were investigated for peanut IgE, $\mathrm{AraH} 2$ positivity and underwent lung function test with exercise challenge before entering an open food challenge (OFC) test. Oral immunotherapy (OIT) with incremental doses was started under a protective medication of levocetirizine with an amount of peanut protein lower than the reaction threshold in the OFC. Maintenance was reached with a dosage of $250 \mathrm{mg}$ peanut protein (2 kernels) and OIT was continued with this amount on a daily basis. Levocetirizine was discontinued after two months symptom free period on maintenance dosage.
\end{abstract}

Settings: Blood samples, lung function tests OFC and initial dose of OIT were carried out in an outpatient setting able to deal with anaphylactic reactions.

Patients: Four patients, three males and one female, aged 6-12years with systemic reactions to peanut in an open challenge test underwent OIT. Patients revealed co-morbidities such as asthma, atopic eczema, other food allergies, pollen allergy and coeliac disease in addition to peanut allergy.

Interventions: During OIT, patients had repeatedly phone contacts with a physician. If extensive side effects occurred, the dosage was stepped down to the dosage formerly tolerated.

Results: All four patients reached the maintenance dose of $250 \mathrm{mg}$ peanut protein ( 2 kernels). The interval between starting OIT and reaching maintenance was 7-35 weeks. Adverse reactions during OIT were considerably mild and consisted of GER, mild to moderate stomach pain and an itchy throat and treated with antihistamine. No one needed adrenalin for the symptoms during OIT.

Conclusions: OIT was effective in patients with mild to moderate anaphylaxis due to peanut allergy using an uncomplicated, individually tailored protocol.

Keywords: Anaphylaxis; Desensitization; Oral immunotherapy; Peanut allergy
Volume I Issue I - 2015

\author{
Rudiger Schultz, ${ }^{1,2}$ Tiina Maki, ${ }^{2}$ Marita \\ Paassilta ${ }^{2}$ \\ 'Medical Center Pihlajalinna, Department of Pediatrics, Tampere \\ Finland \\ ${ }^{2}$ Allergy Center, Tampere University Hospital, Finland
}

Correspondence: Marita Paassilta,Allergy Center,Tampere University Hospital, PB 2000, FIN-3352I Tampere, Finland, Tel 358504405047, Email marita.paassiltapshp.si

Received: March 23, 2015 | Published: April 23, 2015
Abbreviations: GER, gastro-oesophageal-reflux; OFC, open food challenge test; OIT, oral immunotherapy

\section{Introduction}

Trends for treatment of food-allergy have changed during the last decade. Instead of preventing symptoms by eliminating food items, reintroduction of small amounts of allergen or in case of severe symptoms or basic foods, controlled, oral immunotherapy (OIT) became a method of choice for those suffering from food allergy. Several clinical trial protocols for peanut OIT have emerged including complicated and time consuming procedures mainly due to substantial fears of adverse effects probably occurring during OIT. ${ }^{1,2}$ Some studies have further tried sublingual OIT.$^{3}$, and combination therapy with omalizumab ${ }^{4}$

To desensitize four children with a history of mild-to-moderate anaphylaxis (Sampson Grade 1-3) after peanut ingestion, we created a safe and individually tailored protocol for oral immunotherapy using crushed, roasted peanuts with an initial dose lower than the reaction threshold in an open challenge test of each child.

\section{Materials and methods}

The study was conducted with the permission of the Head of the Unit in both centers. Informed consent was obtained from the study participants.

OIT with incremental doses was started under a protective medication of levocetirizine $(5 \mathrm{mg} /$ day $)$ and with an amount of peanut protein lower than the reaction threshold in the OFC. Children aged 6 years or more, Ara $\mathrm{h} 2 \geq 0.35$ and immediate positive reaction in an open challenge test within 3 months prior to initiation of the desensitization protocol were included in the study. Prior to initiation of OIT for peanut, latent or labile asthma was excluded by exercise challenge test with impulse oscillometry (if $<7$ years) or spirometry (if 7 years 
or older). Subsequently, an open challenge test with crushed and roasted peanuts was carried out, starting with a dose of 1:32 of whole peanut (corresponding to $3.9 \mathrm{mg}$ of peanut protein. ${ }^{5}$ ) If symptom less after 2 minutes, the dosage was doubled until food allergy-suggestive symptoms appeared (Eg. urticaria, angioedema, wheezing, dyspnea, allergic rhinitis, conjunctivitis, nausea and/or vomiting, numb and itchy throat or tongue, tachycardia or drop of blood pressure, and doses 1:32, 1:16, 1:8, 1:4, 1:2, 1 and 2 whole peanut kerneals if applicable). Food challenges were carried out in centers capable of dealing with anaphylactic reactions. OIT was started with a dosage lower than the dosage provoking symptoms in the open food challenge (OFC) performed to children before OIT (threshold dose). Subsequently, the patient continued OIT at home and the dosage was increased every two weeks (or individually tailored if mild symptoms occurred) until an amount of 2 whole peanut kernels, (i.e. 1000mg of peanut corresponding to $250 \mathrm{mg}$ of peanut protein) was tolerated. If extensive side effects occurred during desensitization, the patients were guided to contact the center. The dosage was stepped down to the dosage formerly tolerated under the guidance of the pediatric allergist responsible of the protocol. OIT was performed under a medication of levocetirizine $5 \mathrm{mgx} 1 /$ day and phone call access to study center. After reaching maintenance dose of 2 whole peanuts per day levocetirizine was used for two more months and then terminated (Table 1).

Peanut sIgE: Peanut-specific immunoglobulin E; kU/l: kilo units per liter; Ara h2: Arachis hypogea peanut plant; heat-resistant storage protein component present in peanut-allergic persons with potentially severe reactions; Ara h8: Arachis hypogea peanut plant; heat-labile and typically is associated with cross-reactions to pollens.

\section{Results}

During the maintenance (in week 12) patient one underwent an open re-challenge test for peanut protein. He received a dose corresponding 4 whole peanut kernels (i.e. $2000 \mathrm{mg}$ of peanut corresponding to $500 \mathrm{mg}$ of peanut protein) without any symptoms. The three other subjects were not re-challenged. Two to three years later all four subjects continue daily ingestion of peanut (Table 2).

Table I Patient Characteristics

\begin{tabular}{|c|c|c|c|c|c|c|c|c|c|}
\hline Patients & Gender & $\begin{array}{l}\text { Age } \\
\text { (Years) }\end{array}$ & $\begin{array}{l}\text { Symptoms } \\
\text { after Peanut } \\
\text { Ingestion } \\
\text { Prior to OFC }\end{array}$ & $\begin{array}{l}\text { AdreNalin } \\
\text { i.m. (Prior } \\
\text { To OIT) }\end{array}$ & Co-Morbidity & $\begin{array}{l}\text { Other Food } \\
\text { Allergies }\end{array}$ & $\begin{array}{l}\text { Peanut } \\
\text { S-IgE } \\
\text { Ku/L }\end{array}$ & $\begin{array}{l}\text { Ara } \\
\mathrm{H} 2 \\
\mathrm{Ku} / \mathrm{L}\end{array}$ & $\begin{array}{l}\text { Ara } \\
\mathrm{H} 8 \\
\mathrm{Ku} / \mathrm{L}\end{array}$ \\
\hline I & Male & 12 & $\begin{array}{l}\text { Urticaria, } \\
\text { Angioedema, } \\
\text { Dyspnea }\end{array}$ & Yes & $\begin{array}{l}\text { Pollen allergy, } \\
\text { Allergic Rhinitis }\end{array}$ & No & 331 & 78 & I \\
\hline 2 & Female & 7 & $\begin{array}{l}\text { Angioedema, } \\
\text { Stomach Pain, } \\
\text { Vomiting }\end{array}$ & No & Coeliac Disease & Coeliac Disease & 50.5 & 64.4 & $<0.10$ \\
\hline 3 & Male & 6 & $\begin{array}{l}\text { Urticaria, Sore } \\
\text { Throat,Vomiting }\end{array}$ & Yes & Atopic Eczema & No & 83 & 0.56 & $<0.10$ \\
\hline 4 & Male & 6 & No Ingestion & No & Asthma & $\begin{array}{l}\text { Desensi-tized to } \\
\text { Milk and Egg }\end{array}$ & 3.02 & 1.44 & $<0.10$ \\
\hline
\end{tabular}

Table 2 Patient Results

\begin{tabular}{|c|c|c|c|c|c|c|}
\hline Patient & $\begin{array}{l}\text { Reaction } \\
\text { Threshold in } \\
\text { OFC }\end{array}$ & $\begin{array}{l}\text { Symptoms Leading to } \\
\text { Termination of OFC }\end{array}$ & $\begin{array}{l}\text { Adrenalin i.m. } \\
\text { during OFC }\end{array}$ & $\begin{array}{l}\text { Starting } \\
\text { Dosage of } \\
\text { OIT }\end{array}$ & $\begin{array}{l}\text { Time to } \\
\text { Maintenance }\end{array}$ & $\begin{array}{l}\text { Symptoms } \\
\text { during OIT }\end{array}$ \\
\hline I & $\begin{array}{l}\text { I/8 Peanut } \approx 0.0156 \\
\text { G Protein }\end{array}$ & $\begin{array}{l}\text { Numb and itchy throat, } \\
\text { Nausea }\end{array}$ & No & $\begin{array}{l}\text { I/16 Peanut } \approx \\
0.0078 \text { I G Protein }\end{array}$ & 7 weeks & None reported \\
\hline 2 & 3 Peanuts & $\begin{array}{l}\text { Heartburn, Nausea, vomiting, } \\
\text { drop of blood pressure }\end{array}$ & Yes & $\begin{array}{l}\text { I/16 Peanut } \approx \\
0.0078 \text { I G Protein }\end{array}$ & 35 weeks & $\begin{array}{l}\text { Moderate aching o } \\
\text { stomach, GER }\end{array}$ \\
\hline 3 & $\begin{array}{l}\text { I/8 Peanut } \approx 0.0156 \\
\text { G Protein }\end{array}$ & $\begin{array}{l}\text { Numb and itchy tongue and } \\
\text { throat }\end{array}$ & No & $\begin{array}{l}\text { I/24 Peanut } \approx \\
0.00520 \mathrm{G} \text { Protein }\end{array}$ & 7 weeks & $\begin{array}{l}\text { Itchy throat, Mild } \\
\text { aching of stomach }\end{array}$ \\
\hline 4 & $\begin{array}{l}1 / 2 \text { Peanut } \approx \\
0.0625 \mathrm{G} \mathrm{Protein}\end{array}$ & $\begin{array}{l}\text { Nausea, vomiting, pale } \\
\text { appearance }\end{array}$ & No & $\begin{array}{l}\text { I/16 Peanut } \approx \\
0.0078 \text { I G Protein }\end{array}$ & 14 weeks & $\begin{array}{l}\text { Moderate aching o } \\
\text { stomach }\end{array}$ \\
\hline
\end{tabular}




\section{Discussion}

OIT for peanut allergy is tempting for many reasons, mainly because of lifelong fear for serious reactions after accidental ingestion leading to preventive measures such as the prescription of an adrenalin self-injectable-device, on which the patient may become psychologically dependant. On the other hand, the benefit-risk ratio of OIT should be clearly in favor for benefits, minimizing the risks for serious side effects during the procedure. Except for patient 4, all four patients had a history of mild-to-moderate anaphylaxis after peanut ingestion (Sampson Grade 1-3), ${ }^{6}$ at presentation and showed still generalized reactions during the challenge test. Patient 4 had no history of allergic reactions against peanut protein because the parents managed to prevent ingestion due to a history of severe egg and milk allergies. However, during the challenge test, the patient presented intense gastrointestinal symptoms.

All four patients, regardless of their medical history and reaction profile to peanut protein, reached the maintenance dose of two peanut kernels securely in a period of 7-35weeks and continued further with this dosage on a daily basis. Side effects occurring during desensitization were only moderate and interestingly, patient 1 , who had the highest amount of sIgE against Ara h 2 presented with no side effects at all. On the contrary, patient 4 who presented during OIT with moderate stomach pain and gastrointestinal symptoms had only the sIgE titer against Ara h 2 of $1.44 \mathrm{kU} / 1$ but was on asthma medication. Also patient 2 presented with serious gastrointestinal problems having in addition to a high titer of $\operatorname{sIgE}$ against Ara $\mathrm{h} 2$ coeliac diseases as co-morbidity. Although a number of four patients does not allow us to draw conclusions concerning the predictive value of Ara $\mathrm{h} 2$ these observations underline the findings of van Erp et al.7 who have shown that Ara h 2 is predictive for a positive outcome in a food challenge, but its relation to severe reactions is insignificant. ${ }^{8}$

One year after reaching maintenance patient four had accidently taken a considerable higher amount of peanut protein resulting in an itchy throat. Patient one is taking peanut protein without any restrictions, whereas patient two and three continued to take two kernels only on a daily basis. All patients felt considerably relieved from the fear of accidental peanut ingestion and possible consequences. We believe that this simple OIT procedure for peanut allergy by applying an individually tailored desensitization protocol with incremental dosage of crushed peanut powder can be securely carried out for most of the patients. Similar results with a high security profile could also be shown by Yu et al. ${ }^{9}$ However, for patients with the history of life-threatening anaphylactic reactions after peanut ingestion or getting these reactions during challenge tests (Sampson Grade 4-5), lower starting doses like $0.05-0.1 \mathrm{mg}$ or less. ${ }^{3}$ are probably needed to minimize risks for these most sensitive patients. OIT can induce desensitization. The next important question is whether or how OIT can induce tolerance or sustained unresponsiveness..$^{10}$ It is also important to further evaluate the basic mechanisms of OIT. ${ }^{11}$ Careful patient selection is essential due to possible serious adverse events.
Simple protocols are needed for peanut-specific oral immunotherapy. The long-term effect and safety of peanut desensitization remain to be established.

\section{Acknowledgements}

We thank Neil Hopkins for revision on the language of the manuscript.

\section{Conflicts of interest}

The authors declare there are no conflicts of interest related to the article.

\section{Funding}

None.

\section{References}

1. Blumchen K, Ulbricht H, Staden U, et al. Oral peanut immunotherapy in children with peanut anaphylaxis. $J$ Allergy Clin Immunol. 2010;126(1):83-91.

2. Varshney P, Jones SM, Scurlock AM, P, et al. A randomized, controlled study of peanut oral immunotherapy; Clinical desensitization and modulation of the allergic response. J Allergy Clin Immunol. 2011;127(3):654-660.

3. Fleischer DM, Burks A, Vickery BP, et al. Sublingual immunotherapy for peanut allergy:A randomized, double-blind, placebo-controlled multicenter trial. J Allergy Clin Immunol. 2013;131(1):119-127.

4. Schneider LC, Rachid RA, LeBovidge JS, et al. A pilot study of omalizumab to facilitate rapid oral desensitization in high-risk peanutallergic patients. J Allergy Clin Immunol. 2013;132(6):1368-1374.

5. Souci S. Food composition and nutrition tables. $7^{\text {th }}$ edn, London, Stuttgart:Medpharm Scientific Publishers; 2008.

6. Sampson HA (2003) Anaphylaxis and Emergency Treatment. Pediatrics 111(6 Pt 3):1601-1608.

7. van Erp FC, Knulst AC, Kentie PA, et al. Can we predict severe reactions during peanut challenges in children? Pediatr Allergy Immunol. 2013;24(6):596-602.

8. Eller E, Bindslev-Jensen C. Clinical value of component-resolved diagnostics in peanut-allergic patients. Allergy. 2013;68(2):90-194.

9. Yu GP, Weldon B, Neale-May S, et al. The safety of peanut oral immunotherapy in peanut allergic subjects in a single-center trial. Int Arch Allergy Immunol. 2012;159(2):179-182.

10. Vickery BP, Scurlock AM, Kulis M, et al. Sustained unresponsiveness to peanut in subjects who have completed peanut oral immunotherapy. J Allergy Clin Immunol 2014;133(2):468-475.

11. Syed A, Garcia MA, LyuS-C, et al. Peanut oral immunotherapy results in increasedantigen-induced regulatory $\mathrm{T}$-cell function andhypomethylation of forkhead box protein 3 (FOXP3). J Allergy Clin Immunol. 2014;133(2):500-510. 